\title{
Modernidades líricas na poesia de língua portuguesa*
}

\author{
Gustavo Henrique Rückert ${ }^{* *}$
}

A poesia é uma forma de clandestinidade na ditadura do mundo.

Herberto Helder

\section{A poesia e o individualismo moderno}

Quais características assinalam a constituição de uma modernidade lírica? Para Charles Baudelaire (1999), o caráter mnemônico. Para Walter Benjamin (1994), a representação da fugacidade da vida moderna. Para Hugo Friedrich (1991), a dissonância das musicalidades clássicas. Para Ezra Pound (2006), a impossibilidade de redução da interpretação a uma descrição. Para Octavio Paz (2012), a reflexão e a ironia. Para Marshall Berman (1998), a impossibilidade de apreensão do próprio sentido de moderno. Para Jonathan Culler (1999), a expressão retórica no nível máximo de linguagem figurada.

A lista de respostas mencionadas acima, apesar de bastante heterogênea, não é exaustiva. Isso revela, inicialmente, a pluralidade de formas líricas que, de diferentes maneiras, relacionam-se com o que se convencionou chamar modernidade. E mesmo esse recorte histórico, como já alertou Jacques Le Goff (2015), é também problemático. ${ }^{1} \mathrm{O}$ que é ser moderno, afinal de contas? Em comum a todas as definições anteriores, subjaz a crise do individualismo moderno.

Tradicionalmente o gênero lírico foi considerado o gênero da expressão, em oposição à representação. Para Platão (1980), foi considerado não mimético. Para Aristóteles (2005), sequer foi considerado poético, pois só o eram os gêneros que representavam a realidade. Se odes, elegias e éclogas eram pouco valorizadas na antiguidade, na modernidade passaram a ser bastante valorizadas. As cantigas trovadorescas popularizaram as formas líricas na baixa idade média. A ascensão da

\footnotetext{
Artigo resultante do projeto de pesquisa Poesia e modernidade nas literaturas em língua portuguesa (2018-2020).

* Doutor em Literaturas Portuguesa e Luso-Africanas e professor de Literatura em Língua Portuguesa na Universidade Federal dos Vales do Jequitinhonha e Mucuri (UFVJM), Diamantina, MG, Brasil. E-mail: gh.ruckert@gmail.com.

1 Na historiografia, diversos são os índices apontados para definir a idade moderna, como: revolução francesa; ascensão da burguesia; expansão marítima; reforma protestante; advento da imprensa; entre outros.
} 
burguesia, a reforma protestante, o advento da imprensa, as filosofias racionalista e empirista, a política do liberalismo, entre outros, consagraram o indivíduo moderno como ser racional, consciente e livre. O contexto não poderia ser mais propício à expressão de sua subjetividade. Daí o gênero lírico passar a ser valorizado no renascimento (com o advento do soneto) e ser o mais elevado no século XIX, por meio da estética romântica.

Em suas Preleções sobre a Estética, Friedrich Hegel (1997) chegou a afirmar que a obra de arte é a produção do espírito, pelo espírito e para o espírito. Dessa forma, a manifestação de um geist ou ellán dava-se pela plena aproximação entre eu-empírico e eu-lírico encenada pela lírica romântica. Nada mais representativo do culto ao indivíduo moderno que essa espécie de teoria da transparência criativa.

Podemos compreender que a lírica moderna se relaciona com a modernidade histórica em uma dialética de negação (ADORNO, 2003). A modernidade histórica está pautada em uma espécie de mito do eu: individualismo, consciência, racionalismo, empirismo, liberalismo. A modernidade lírica está pautada justamente na falência desse eu, seja por meio da fragmentação, da dispersão, do inconsciente, de um caráter mimético (e não mais apenas expressivo), da cisão entre linguagem e realidade, e assim por diante. A poesia é moderna em Baudelaire? Em Mallarmé? Em Rimbaud? Em Maiakovski? Em Tzara? Em Breton? Em Apollinaire? Em Marinetti? Em Pound? Em Eliot? A depender do corpus poético selecionado, diferentes noções de modernidade são depreendidas em diferentes manifestações de eus que frustram o mito de um indivíduo moderno unitário e estável.

Neste estudo, será abordada a modernidade lírica em língua portuguesa em três diferentes vertentes: a modernidade lírica portuguesa, brasileira e africana - sobretudo angolana e moçambicana. Para isso, serão analisados poemas de Fernando Pessoa, Oswald de Andrade e Agostinho Neto, respectivamente. Ao longo das análises, serão referidos também poemas de Florbela Espanca, Mário de SáCarneiro, Mário de Andrade, Carlos Drummond de Andrade, Noémia de Sousa e José Craveirinha.

\section{Fernando Pessoa a outrar-se}

Uma das principais marcas da poesia portuguesa no início do século XX é a multiplicidade. Apesar de Lisboa não passar por transformações sociais e culturais tão intensas quanto Paris ou Londres, o cosmopolitismo, a urbanização, o dinamismo, o comércio, a imprensa, o anonimato, entre outras características, tornam-se mais frequentes na poesia, substituindo a natureza romântica de Garrett ou Herculano e o racionalismo proudhoniano de Quental. Tais marcas aparecem já no final do século XIX em António Nobre e, principalmente, Cesário Verde. É com Florbela Espanca e com os orphistas, no entanto, que se solidificam, cindindo a ideia de uma individualidade estável do eu-lírico. No poema "Eu", o eu-lírico florbeliano afirma: "Eu sou a que no mundo anda perdida, / Eu sou a que 
na vida não tem norte"; mais adiante: "Sou talvez a visão que Alguém sonhou" (EsPANCA, 2010, p 127). Em “Dispersão”, de Sá-Carneiro, o eu-lírico lamenta:

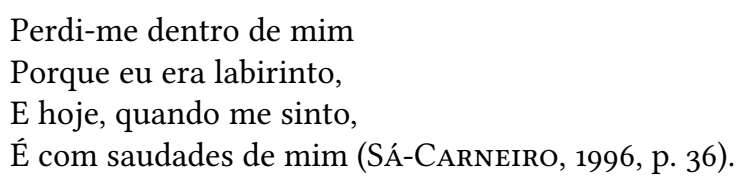

Nos demais poemas de ambos, é extremamente comum a utilização de imagens imprecisas como "sombra", "névoa", "bruma", "quimera", "espuma", "cores" e "aromas", para que o sujeito-lírico possa se (in)definir. Há nos poemas dos dois poetas uma busca incessante por uma identidade descrita por imagens. No entanto, ela nunca é possível senão por imagens etéreas, sem forma fixa. É o eu moderno que se mira na alteridade anônima das metrópoles ou no profundo pensamento e não se reconhece. Daí a importância do outro para essa incompreensão do sujeito lírico: "Alguém", "Outro", "pobre moço das ânsias".

Se as poéticas de Florbela e Sá-Carneiro trazem a perturbação da noção de fragmentação da unidade identitária do indivíduo moderno, em Fernando Pessoa temos justamente a celebração dessa crise. Em diálogo com vanguardas como o futurismo e o cubismo, Pessoa (1986) propõe em Portugal a vanguarda do sensacionismo, que consistiria em sentir tudo de todas as formas. Ora, tal radicalização do sentimento só é possível com a radicalização da alteridade. E Pessoa a faz. Nos poemas assinados pelo ortônimo, apresenta uma teoria de criação poética que podemos definir como "princípio do fingimento" (Tutikian, 2006, p. 12). Essa estética consiste na separação completa entre eu-lírico e eu-empírico. De acordo com o próprio poeta (1986), tal característica seria como misturar elementos do drama e da lírica tradicionais, criando assim personagens para expressarem de forma lírica as mais distintas formas de sentir. Na já bastante repetida estrofe inicial de "Autopsicografia”, enfatiza-se a criação de sensações, em oposição à romântica expressão:

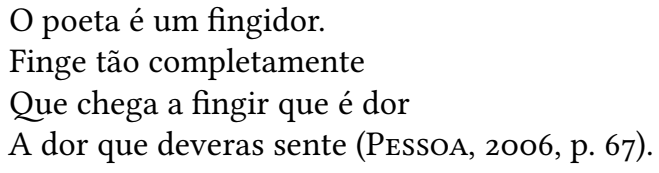

Também na primeira estrofe de "Isto", a importância da criação das emoções escritas nos poemas é destacada:

\author{
Dizem que finjo ou minto \\ Tudo que escrevo. \\ Não. Eu simplesmente sinto \\ Com a imaginação. \\ Não uso o coração (PESSOA, 2006, p. 68).
}


Bem criadas, as emoções de papel são capazes de emocionar aquele que lê, como fica claro na segunda estrofe de "Autopsicografia":

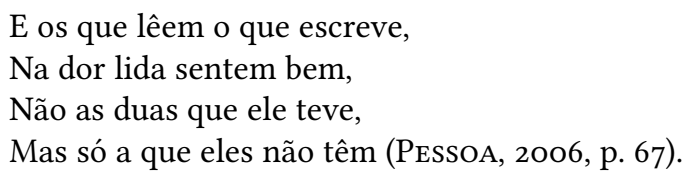

A aplicação do "princípio do fingimento" em seu projeto literário leva Pessoa à criação de mais de uma centena de personalidades literárias, que darão origem a diferentes sujeitos líricos e narradores de obras em verso e prosa. Tal atitude é tão recorrente na vida do poeta que sua primeira criação é Chevalier de Pas, logo aos seis anos de idade. Suas criações mais famosas são as dos três heterônimos (personalidades com nome, biografia e estilos próprios): Alberto Caeiro, Ricardo Reis e Álvaro de Campos. Entre o pensador autodidata de versos livres, o médico de odes neoclássicas à Horácio e o engenheiro naval viciado em ópio de inspiração futurista há pouquíssimos elementos comuns. Para Pessoa, em carta a Adolfo Casais Monteiro, isso explica um traço de "histeria profunda" de sua personalidade: a tendência a "outrar-se" (PessoA, 1986, p. 85).

Ao analisar a produção do semi-heterônimo Bernardo Soares, a crítica literária Leyla Perrone-Moisés comenta aquilo que é também característica de outras personalidades literárias pessoanas: "Bernardo Soares, como os outros Pessoas, sofre da solidão povoada de um ego ausente, de um centro cego e jamais assente" (Perrone-Moisés, 2001, p. 221). Sem um centro de sentidos assente na subjetividade de um eu cartesiano, os eus dos poemas de Pessoa estão dispersos no outro, nos fragmentos de cenários descritos, nas narrativas não lineares formadas nos poemas que acabam por sobrepor distintas temporalidades. Trata-se da impossibilidade da representação do espaço, como assinalado por Baudelaire, da fugacidade da temporalidade moderna de Benjamin, e de uma tendência psicológica para o inconsciente, para o fluxo e para a alteridade que seria radicalizada pelos surrealistas. Logo no início de "Tabacaria", Campos afirma:

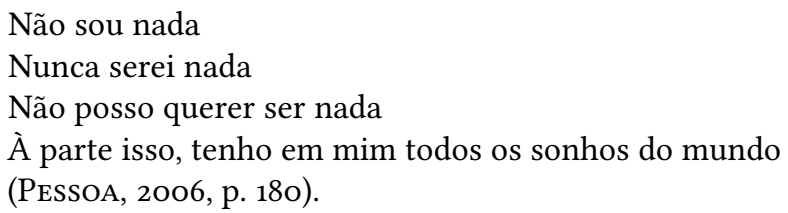

As reiterações dos advérbios de negação e de totalidade no início e no fim dos três primeiros versos, bem como a manutenção do padrão de acentuação, sentenciam a impossibilidade de o sujeito moderno definir-se em uma identidade fixa, estável, essencialista. A ruptura desses padrões no quarto verso aponta para a explicação de que não é possível ser um, por ser muitos. 
É-se um pouco de toda alteridade, seja ela formada por pessoas, espaços, tempos, que nos atravessam. Dessa forma, a poesia portuguesa demarca sua modernidade na fragmentação radical do sujeito lírico, um eu que está sempre "outrado", o qual, falando tanto de si quanto do outro, é muitos. Ameaçando a unidade individual, ele ameaça a visão de mundo individualista que prevalecia com a pequena burguesia lusitana. Daí Sá-Carneiro (2003) considerar o burguês português como "lepidóptero", Almada Negreiros (2012) considerar que o pior do burguês português é o ser português e Pessoa comemorar a má recepção da revista Orpheu ${ }^{2}$ pelo público médio português: "Somos o assunto do dia em Lisboa; sem exagero lho digo. O escândalo é enorme” (PessoA, 1986, p. 414).

\section{A poesia existe nos fatos ou Oswald de Andrade}

Se pensarmos na produção poética de nomes do fim do século XIX e início do século XX brasileiro, como Alphonsus de Guimaraens, Cruz e Sousa ou Augusto dos Anjos, encontraremos uma vertente psicológica, simbolista e decadentista que se assemelha a Florbela e Sá-Carneiro na utilização de imagens imprecisas para (in)definir o sujeito lírico. "Sonhos", "brumas", "sombras", "escuridão", "aurora", "luar", "fantasmas", "sons", "aromas", "elementos químicos e zodíacos" são algumas das metáforas que (de)compõem a imagem de um eu fragmentado entre o outro e as paisagens. Como dito no soneto "Cantem outros a clara cor virente", de Alphonsus de Guimaraes (2020, n.p.), "Cada um de nós é a bússola sem norte".

Apesar dessa vertente finissecular, os movimentos modernistas do início do século XX consagraram outros rumos à poesia brasileira, bastante distintos do investimento intimista do orphismo em Portugal. O modernismo brasileiro ganhou contornos de nacionalismo. Para isso, o anti-lusitanismo foi uma de suas pedras fundamentais, motivo pelo qual os modernistas portugueses foram pouquíssimo lidos pelos poetas brasileiros, conforme aponta o pesquisador Arnaldo Saraiva (1986).

Dentro do projeto de um modernismo nacional destacaram-se na geração de 1922, sem dúvida, Mário de Andrade e Oswald de Andrade. Aquele se debruçou no estudo do folclore nacional, sobretudo indígena, resultando na rapsódia $\mathrm{Macu-}$ naíma, por exemplo. Este, em poemas curtos e narrativos, os poemas pílula, além de manifestos ao estilo das vanguardas europeias.

Nesse sentido, destaca-se o Manifesto da poesia pau-brasil. Logo nas suas primeiras linhas, já se atenta para a necessidade de representação da realidade nacional na poesia: "A poesia existe nos fatos. Os casebres de açafrão e de ocre nos verdes da favela, sob o azul cabralino, são fatos estéticos" (ANDRADE, 2009, p. 472). Dessa forma, a poesia moderna brasileira investiu em um aspecto mais sociológico ou, por vezes, antropológico, já que deveria se expressar em linguagem "sem arcaísmos, sem erudição. Natural e neológica. [...] como falamos, como somos”

\footnotetext{
2 Revista literária portuguesa de caráter vanguardista idealizada por Fernando Pessoa e Mário de
} Sá-Carneiro no ano de 1915. 
(ANDRADE, 2009, p. 473). De maneira irônica, então, deveria unir a escola e a floresta, isto é, o lado doutor e o lado carnaval, ou, como dito no Manifesto antropófago (2009), deglutir todas as influências e torná-las algo nacional. Daí a importância da parodia na poesia oswaldiana, recurso empregado para a releitura dos textos de viés antropológico da literatura de viagem lusa, como em "Erro de português":

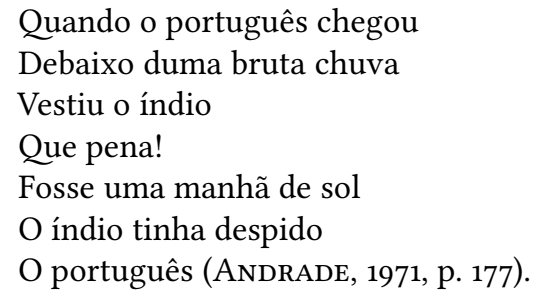

Para além do riso, ou justamente pelo riso, há em sua irreverente poética um investimento sério na releitura da história nacional, sobretudo da colonização, evidenciando as relações de poder entre colonizador e colonizado. Afasta-se assim da lírica mais convencional, da noção de expressão de uma subjetividade, para propor uma (anti)lírica que dialoga com o ensaio (esse gênero tão latino-americano). Em "As meninas da gare" (ANDRADE, 1971, p. 80) ou "O capoeira" (ANDRADE, 2009, p. 94), utiliza dos mesmos elementos para chamar atenção à condição da população brasileira no presente como resultado do passado colonial. Em "Pronominais" (ANDRADE, 2009, p. 125) ou "Vício na fala" (ANDRADE, 2009, p. 89) seu ataque dirige-se à gramática lusitana imposta ao brasileiro.

Para o crítico literário Antonio Candido, "frequentemente a sua escrita é feita de frases que se projetam como antenas móveis, envolvendo, decompondo o objeto até pulverizá-lo e recompor numa visão diferente" (CANDIDO, 1977, p. 78). Essa visão não é exatamente de uma transmutação poética no sentido da imagem reapresentada de modo mais estético ou lírico. É uma visão diferente no sentido crítico. Em Oswald, para Candido, "tudo é diferente, desde a linguagem nua e incisiva, toda concentrada na sátira social, até a despretensão da atitude literária, despreocupada em aformosear a vida" (CANDIDO, 1992, p. 19).

Sua sátira social formulada em uma poesia com elementos ensaísticos e anedóticos é direcionada especificamente à burguesia paulista de que faz parte, seus hábitos e seus valores. Denuncia assim a colonialidade da classe que passa a deter o poder econômico do país no século XX. Em Mário de Andrade, essa crítica em tom irônico e ensaístico se torna mais explícita ainda:

Eu insulto o burguês! O burguês-níquel

o burguês-burguês!

A digestão bem-feita de São Paulo!

O homem-curva! O homem-nádegas! (ANDRADE, 1987, p. 88). 
Em suma, principalmente em Oswald, mas não se restringindo a ele, a modernidade lírica brasileira investiu em uma poética que não fala muito do eu, em que pouco importa a vivência empírica individual e a expressão romântica da subjetividade. Trata-se de uma poesia para falar da sociedade, da história e da cultura brasileira.

Uma outra vertente modernista do país, cujos expoentes são Carlos Drummond de Andrade e Manuel Bandeira, abrandaria esse viés ensaístico e voltaria à subjetividade em meados do século XX. No entanto, a poesia continuaria "existindo nos fatos" e bem-humorada, apenas menos ensaística, mais tomada pela musicalidade popular e entremeada por um sujeito lírico que manifesta intensamente sua subjetividade. No entanto, esse eu já é um eu decomposto em sete faces, todo retorcido ou vivendo as agruras do aqui, mas desejando ir embora para a idílica Pasárgada.

Assim, esse eu bem-humorado, mas melancólico, ao mesmo passo em que fala de si não deixa de falar da realidade nacional e suas contradições herdadas da história colonial, como fica evidente em "Explicação", de Drummond:

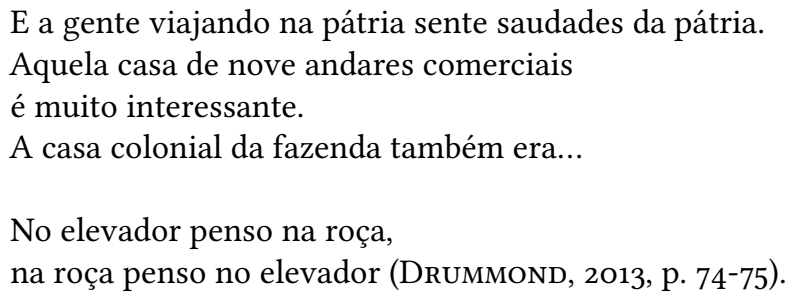

E o sujeito-lírico prossegue em síntese entre análise social e reflexão existencial:

Quem me fez assim foi minha gente e minha terra e eu gosto bem de ter nascido com essa tara.

Para mim, de todas as burrices a maior é suspirar pela Europa (Drummond, 2013, p. 74-75).

\section{Nós somos: Agostinho Neto}

Muito se fala a respeito da influência da poesia modernista brasileira, sobretudo Bandeira, Drummond, Cabral, Oswald e Mário, para os poetas africanos de língua portuguesa de meados do século XX, como Oswaldo Alcântara, Jorge Barbosa, Ovídio Martins, Agostinho Neto, Alda Lara, José Craveirinha, Noémia de Sousa. Muito se fala também sobre os aspectos revolucionários, anticoloniais, independentistas, socialistas ou da negritude nesses poetas. Todavia, pouco se fala sobre a modernidade lírica em sua poesia.

Se a modernidade lírica se configura menos por um recorte cronológico e mais pela atitude de assinalar, por distintas formas estéticas, a impossibilidade de individuação moderna, é a partir da década de 1940 que isso se torna frequente na 
lírica africana de língua portuguesa, especialmente nos casos de Angola e de Moçambique. Vale ressaltar, ainda, que o mito do indivíduo moderno foi, juntamente com a colonização, alicerce da moderna sociedade europeia. Para garantir as liberdades individuais aos cidadãos europeus, era necessário negar a cidadania e a individualidade dos povos africanos, cuja exploração sustentava o desenvolvimento e o progresso das metrópoles. Desse modo, construir uma lírica angolana ou moçambicana passava, necessariamente, por desconstruir o mito do indivíduo moderno - tão propagado na tradição lírica ocidental. Essa solução estava bastante próxima de poetas como Agostinho Neto, José Craveirinha ou Noémia de Sousa, que almejavam construir um sentimento de pertencimento a Angola e a Moçambique por meio da poesia, algo fundamental às futuras independências. A solução estava nas próprias culturas locais.

Em Adeus à hora da largada, tradicional poema de Agostinho, há uma importante dubiedade na utilização do pronome a partir do qual se expressa o eu-lírico, ora "eu", ora "nós". Essa dubiedade também é direcionada à interlocutora: Minha Mãe / (todas as mães negras / cujos filhos partiram)" (NETO, 2018, n.p.). O poema trata da despedida do(s) filho(s), que parte(em) rumo à vida, metáfora da independência: "Nós vamos em busca de luz / os teus filhos Mãe / (todas as mães negras / cujos filhos partiram) / Vão em busca de vida". Essa vida é a esperança de um futuro de liberdade, em oposição ao passado de colonialismo, escravidão, trabalhos forçados e miséria recuperados pelo poema. Trata-se de uma convocação à luta. Por isso, o eu-lírico é um "eu" que se expressa, no entanto esse "eu" é também todos os angolanos.

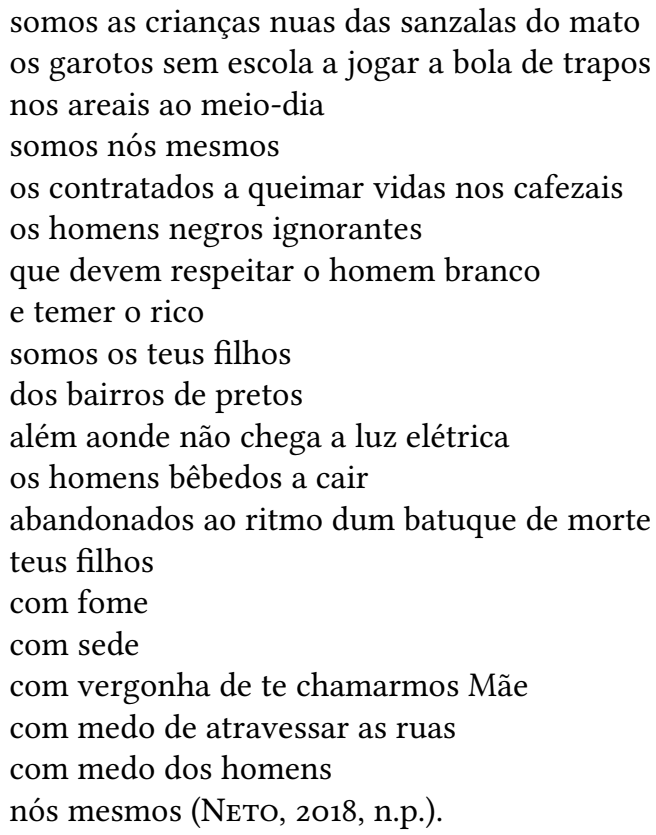


Tal constituição de um eu-lírico representativo de uma coletividade é recorrente na poética de Agostinho. Em Aspiração, o eu expressa seu canto de lamento que é o mesmo canto de lamento de todos os sujeitos negros, da África ou da diáspora: "Ainda o meu canto dolente / e a minha tristeza / no Congo, na Geórgia, no Amazonas" (Neto, 2018, n.p.). Em Noite, o sujeito lírico define-se a partir do espaço comum a todos os sujeitos negros: favelas, guetos, musseques.

\section{Eu vivo}

nos bairros escuros do mundo

sem luz nem vida. [...]

São bairros de escravos

mundos de miséria

bairros escuros.

Onde as vontades se diluíram

e os homens se confundiram

com as coisas (NETO, 2018, n.p.).

Essa constituição de um eu-lírico plural, que pode ser qualquer angolano, qualquer africano, qualquer negro, difere-se da ideia de coletividade expressa no neorrealismo, por exemplo. Trata-se da hibridação ${ }^{3}$ do gênero lírico com a visão de mundo de culturas africanas para as quais não existe individualidade, pois a vida está dispersa no todo, envolvendo as pessoas, os vivos, os mortos, as árvores, os animais, etc. Essa noção de mundo, comum a várias religiões africanas, é definida teoricamente pelo termo animismo (Cf. GARUBA, 2003).

Não à toa, em Aspiração, o eu-lírico oferece a sua vida individual, no sentido moderno europeu, à vida coletiva, no sentido cultural africano: "Ainda a minha vida / oferecida à Vida" (NETO, 2018, n.p.). A vida que importa é a segunda, a que está nos mortos, nas crianças, nos elementos da natureza. É para sua preservação que seria preciso lutar contra o colonialismo.

Não só na poética de Agostinho Neto ocorre essa apropriação da tradição lírica ocidental para hibridação cultural e transformação em algo próprio das culturas africanas, passando-se da expressão de uma subjetividade para a manifestação de uma vida que não se encerra no eu. No conhecido poema "Grito negro", por exemplo, de José Craveirinha (2008, p. 19), o eu-lírico utiliza-se da metáfora do carvão para definir-se como força de trabalho explorada pela empreitada colonial, mas também como força motriz capaz de gerar revolução. Esse eu é, então, todos os

3 Estudar uma literatura africana implica assinalar a deformação dos modelos ocidentais nos processos de apropriação pelos africanos, em processos que vão da "cópia" (século XIX) à ruptura e carnavalização (Bakhtin), mas, também, incorporar esses processos de diálogo com as diferentes culturas indígenas, que continuaram a ser produzidas nas línguas nacionais, bem como as suas formas transmitidas oralmente (LEITE, 2012, p. 155). 
moçambicanos, africanos ou negros que são explorados e que resistem ao colonialismo. Em Poema do futuro cidadão, o sujeito lírico despersonaliza-se para ser qualquer moçambicano:

\author{
Vim de qualquer parte \\ de uma Nação que ainda não existe. \\ Vim e estou aqui! \\ Não nasci apenas eu \\ nem tu nem outro... \\ mas irmão (CRAVEIRINHA, 2008, p.24).
}

Também em Noémia de Sousa é bastante visível um eu-lírico que não é simplesmente eu, mas nós. Em "Se me quiseres conhecer", o sujeito lírico define-se a partir das mais diferentes imagens de distintas realidades sociais e culturais moçambicanas:

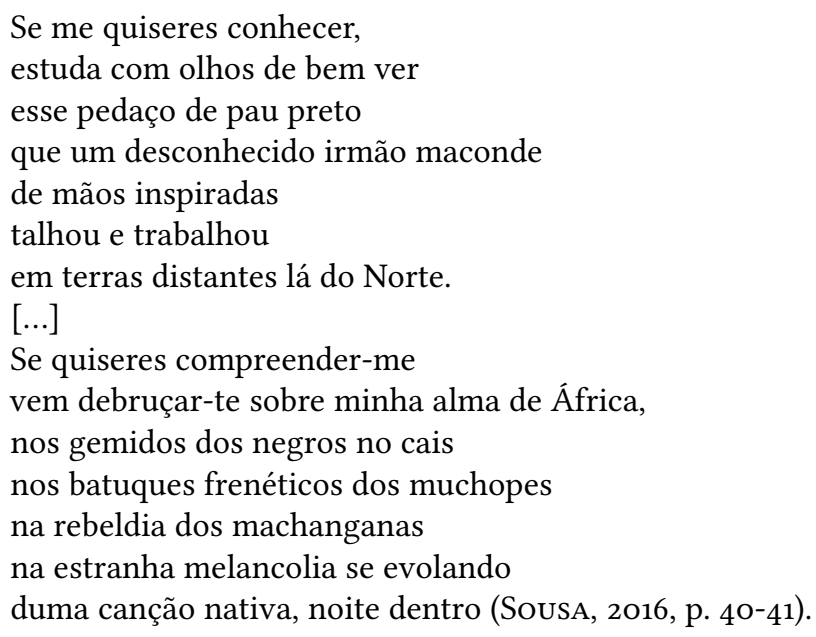

A tradicional cultura maconde, do Norte do país, a cultura urbana do cais, as tradicionais culturas muchope e machangana, do Sul, nada disso é o suficiente para representar o eu-lírico, pois não é um: é um nós. É qualquer "búzio de carne / onde a revolta de África congelou / seu grito inchado de esperança" (SousA, 2016). Da mesma forma em Poema e $A$ minha dor, o eu-lírico é o negro que resiste à prisão e à tortura, o negro que grita "basta" à opressão colonial, ou seja, não é um apenas.

Para a crítica literária Ana Mafalda Leite (2018, p. 176), a poética de Craveirinha é responsável pelo estabelecimento da tradição fundadora da modernidade na literatura moçambicana. Acrescentaríamos aí Noémia e Agostinho, esse último no caso da literatura angolana. Para a pesquisadora, "nas suas múltiplas vertentes, os autores africanizaram e reequacionaram essa modernidade". Esse processo de africanização está na desconstrução da subjetividade lírica para a reequação do gênero, resultando "entre narrativa, canto e escrita, [...] a hesitação enriquecedora 
que o próprio poeta imprime nos seus versos, fazendo-os participar de um estatuto cultural próximo à oralidade" (LEITE, 2018, p. 183).

Dessa maneira, a escrita de uma modernidade lírica africana está na rasura do individualismo moderno europeu, que sustentou a colonização, no próprio âmbito da lírica. Trata-se, portanto, de uma poética que se aproxima dos cantos e das narrativas orais para não se limitar a uma subjetividade, expondo a ideia de uma vida ampla, plena, no sentido animista que a vida adquire para as culturas tradicionais. Como afirmou o eu-lírico (e talvez fosse mais adequado falar nóslírico) agostiniano, em "Mussunda amigo", "Nós somos / Mussunda amigo / Nós somos!” (Neto, 2018, n.p). Para o verbo ser, no sentido africano da existência, não é necessário um sujeito individualizado tampouco predicativo do sujeito.

\section{O eu é uma invenção da linguagem}

A modernidade ocidental sustentou-se, sobretudo, em uma noção essencialista do ser. As teorias de Descartes, Locke, Smith, entre outros, são sintomas de uma noção de um indivíduo unitário, racional, consciente, livre, repleto de experiências e com seus direitos garantidos pelo Estado. A poesia lírica foi um dos principais instrumentos dessa individuação. A expressão lírica de um eu apartado da sociedade, ora pelo seu sentimentalismo romântico, ora pela sua análise cartesiana dessa sociedade, configurou no século XIX um dos ápices da manifestação do indivíduo moderno. No entanto, se a poesia ajudou a construir esse eu monódico, também ajuda a desconstruí-lo. A lírica moderna, nesse sentido, configura-se como uma negação do individualismo moderno. Para Octavio Paz,

O que distingue a revolução da idade moderna das antigas não é tanto nem exclusivamente a corrupção dos primitivos ideais, nem a degradação de seus princípios libertadores em novos instrumentos de opressão, quanto a impossibilidade de consagrar o homem como fundamento da sociedade (PAZ, 1994, p. 67).

O início do século XX, marcado por guerras, ditaduras e colonialismo, evidencia a falência dos paradigmas do pensamento moderno. Se o eu da modernidade ocidental é uma construção de linguagem consolidada pela filosofia, pela poesia, pelo romance, pela autobiografia, pelas leis, pelos partidos políticos, então é necessariamente também uma construção ideológica, visto que não existe linguagem alheia ao social. Investir linguisticamente contra uma noção unitária de subjetividade é investir contra a ideologia da burguesia ocidental, a qual sustentou os trágicos episódios da modernidade. Por esse motivo, no prefácio de Anti-Édipo, de Deleuze e Guatarri, Michel Foucault aponta o indivíduo como último reduto do fascismo:

O indivíduo é produto do poder. O que é preciso é "desindividualizar" pela multiplicação e o deslocamento, o agenciamento de combinações diferentes. O grupo não deve ser o liame orgânico que une indivíduos 
hierarquizados, mas um constante gerador de "desindividualização" (FoucAUlt, 2010, p. XIV).

Pela sua capacidade social e manifestação singular de linguagem, a poesia carrega em si essa potência de "desindividualização". A lírica moderna é, portanto, antes de mais nada, um investimento linguístico contra o fascismo ${ }^{4}$ que a própria modernidade construiu. Justamente por fugir à uniformidade do eu, múltiplas são as formas que o lirismo moderno encontrou para se manifestar. Na poesia escrita em língua portuguesa, universo tão amplo e complexo, evidentemente não há como homogeneizar uma única modernidade lírica.

Nesse sentido, procuramos neste estudo perceber as linhas principais de modernidade nas líricas portuguesa, brasileira e africana (com ênfase para Angola e Moçambique). Não se trata, portanto, de uma descrição precisa ou objetiva que pretenda esgotar as formas com que essas literaturas investiram contra o individualismo moderno.

Ao abordar um corpus poético centralizado em Fernando Pessoa, Oswald de Andrade e Agostinho Neto, sempre em diálogo com outros poetas contemporâneos a esses, acabamos por perceber três estratégias líricas distintas para descentrar a noção de indivíduo moderno. Em Portugal, foi constatado o mergulho em uma poesia intimista, psicológica, urbana, cosmopolita, a qual por meio do fragmento, da impressão, da sinestesia, entre outros recursos, dilui as fronteiras entre o eu e o outro, entre pessoas e paisagens. Já no Brasil, percebeu-se o investimento em uma poesia expansiva, sociológica, ensaística, anedótica, a qual, por meio do humor, da ironia, da paródia, entre outros, acaba por centrar-se na análise da história e do presente nacional. Por fim, na África independente de Portugal, percebemos a constituição de uma modernidade lírica expansiva, oral, em constante diálogo com as culturas locais para encontrar um conceito de vida animista, o qual não está limitado ao indivíduo, mas disperso no todo.

Maiakovski, Jakobson, Pound, Gullar, entre outros poetas e críticos, já chegaram a se referir à poesia como aquilo que provoca espanto pelo caráter inusitado com que (des)organiza a linguagem. Pessoa, Oswald e Agostinho, assim como Florbela, Sá-Carneiro, Mário, Drummond, Craveirinha, Noémia, espantam-nos. Seus poemas nos perturbam por investir contra a mínima e mais elementar estrutura de poder social construída na modernidade: o indivíduo.

\section{Referências}

Adorno, Theodor. Notas de literatura I. São Paulo: Editora 34, 2003.

4 E não somente o fascismo histórico de Hitler e Mussolini - que soube tão bem mobilizar e utilizar o desejo das massas -, mas também o fascismo que está em todos nós, que ronda nossos espíritos e nossas condutas cotidianas, o fascismo que nos faz gostar do poder, desejar essa coisa mesma que nos domina e explora (Foucault, 2010, p. XIII). 
Andrade, Carlos Drummond de. Alguma poesia. São Paulo: Companhia das Letras, 2013.

Andrade, Mário de. Pauliceia desvairada. Belo Horizonte: Itatiaia, 1987.

Andrade, Oswald de. Poesias reunidas. Rio de Janeiro: Civilização Brasileira, 1971.

Andrade, Oswald de. Manifesto antropófago. In.: Telles, Gilberto Mendonça. Vanguarda europeia \& modernismo brasileiro. Petrópolis: Vozes, 2009. p. 504-511.

Andrade, Oswald de. Manifesto da poesia pau-brasil. In.: Telles, Gilberto Mendonça. Vanguarda europeia \& modernismo brasileiro. Petrópolis: Vozes, 2009. p. $472-478$.

Aristóteles. Arte poética. In.: Aristóteles, Horácio, Longino. A poética clássica. São Paulo: Cultrix, 2005. p.17-52.

Baudelaire, Charles. Sobre a modernidade: o pintor da vida moderna. Rio de Janeiro: Paz e Terra, 1999.

Benjamin, Walter. Obras escolhidas III: Charles Baudelaire: um lírico no auge do capitalismo. São Paulo: Brasiliense, 1994.

BERMAN, Marshall. Tudo que é sólido desmancha no ar: a aventura da modernidade. São Paulo: Companhia das Letras, 1998.

Candido, Antonio. Vários escritos. São Paulo: Duas Cidades, 1977.

CAndido, Antonio. Brigada ligeira e outros escritos. São Paulo: Ed. Unesp, 1992.

Craveirinha, José. Xigubo. Maputo: Alcance Editores, 2008.

Culler, Jonathan. Teoria literária: uma introdução. São Paulo: Beca, 1999.

Espanca, Florbela. Poesia de Florbela Espanca. Porto Alegre: L\&PM, 2010.

Foucault, Michel. Preface: Introduction to the non-fascist life. In.: Deleuze, Gilles; Guattari, Felix. Anti-Oedipus: capitalism and schizophrenia. Minneapolis: University of Minnesota Press, 2010.

Friedrich, Hugo. Estrutura da lírica moderna. São Paulo: Duas Cidades, 1991.

GARUBA, Harry. Explorations in animist materialism: notes on reading/writing African literature, culture and society. In: Public Culture 15, n. 2, 2003, p. 261-285.

Guimarães, Alphonsus de. Poemas. Disponível em: http://www.dominiopublico. gov.br/download/texto/bvoooo13.pdf. Acesso em: 28 de março de 2020.

HEgel, Friedrich. Preleções sobre a Estética. In: O belo autônomo. Organização e seleção de Rodrigo Duarte. Belo Horizonte: UFMG, 1997.

LE Goff, Jacques. A História deve ser dividida em pedaços? São Paulo: Editora UNESP, 2015. 
Leite, Ana Mafalda. Cenografias pós-coloniais \& Estudos sobre literatura moçambicana. Lisboa: Edições Colibri, 2018.

LeIte, Ana Mafalda. Oralidades \& escritas pós-coloniais. Rio de Janeiro: Ed. UERJ, 2012.

Negreiros, Almada. Manifesto anti-Dantas e por extenso. Disponível em: http: //www.gutenberg.org/catalog/world/readfile?fk_files=1534331. Acesso em: 25 de maio de 2012.

Neto, Agostinho. Sagrada esperança. Luanda: Fundação Agostinho Neto, 2018. Disponível em: http://www.agostinhoneto.org/index.php?option=com_content\& view $=$ category $\&$ id $=45$ : sagrada- esperanca $\&$ Itemid $=233 \&$ layout $=$ default. Acesso em: 30 de março de 2020.

PAz, Octavio. O arco e a lira. São Paulo: Cosac Naify, 2012.

PAz, Octavio. Os filhos do barro: do romantismo à vanguarda. Rio de Janeiro: Nova Fronteira, 1994 .

Perrone-Moisés, Leyla. Fernando Pessoa: aquém do eu, além do outro. São Paulo: Martins Fontes, 2001.

Pessoa, Fernando. Antologia poética. Porto Alegre: Leitura XXI, 2006.

PessoA, Fernando. Obras em prosa. Rio de Janeiro: Nova Aguilar, 1986.

Platão. A República. Lisboa: Calouste Gulbenkian, 1980.

Pound, Ezra. $A B C$ da literatura. São Paulo: Cultrix, 2006.

SÁ-Carneiro, Mário de. Correspondência com Fernando Pessoa. Lisboa: Relógio d'água, 2003.

SÁ-CARneiro, Mário de. Poemas completos. Lisboa: Assírio \& Alvim, 1996.

Saraiva, Arnaldo. Modernismo brasileiro e modernismo português. Porto: Editora Porto, 1986.

SousA, Noémia de. Sangue negro. São Paulo: Kapulana, 2016.

Tutikian, Jane. Apresentação. In.: PessoA, Fernando. Antologia poética. Porto Alegre: Leitura XXI, 2006. p 9-41.

Recebido em 5 de abril de 2020.

Aprovado em 8 de abril de 2021. 


\section{Resumo}

\section{Modernidades Líricas na Poesia de Língua Portuguesa}

\section{Gustavo Henrique Rückert}

Este artigo tem como objetivo principal investigar os diferentes caminhos que a moderna poesia de língua portuguesa assumiu em três diferentes contextos: Portugal, Brasil e países africanos de língua portuguesa. O corpus poético analisado é constituído principalmente por Fernando Pessoa, Oswald de Andrade e Agostinho Neto. No entanto, são referidos na análise poemas de Florbela Espanca, Mário de Sá-Carneiro, Mário de Andrade, Carlos Drummond de Andrade, Noémia de Sousa e José Craveirinha. Os resultados apontam para três distintas formas de dissolução da noção de individualismo moderno nas três poéticas: uma tendência intimista que visa à fragmentação do eu em Portugal; uma tendência que aproxima poesia e ensaio por meio da descrição da realidade social no Brasil; e uma tendência animista africana que torna a voz poética mais coletiva.

Palavras-chave: modernidade, lírica, poesia em língua portuguesa. 